\title{
REAL OPTION ANALYSIS (ROA)
}

\author{
Armanto Witjaksono ${ }^{1}$
}

\begin{abstract}
Net Present Value (NPV) method have populer since middle 70's and now most of expert felt that method has several limitation, especially if used to analyse big scale investment alocation capital. Another method that begin to popular is Real Option Analysis (ROA) that use to replace Net Present Value (NPV) method. The strenght of Real Option Analysis (ROA) method is the flexiblelity in giving information for the decision maker. The weakness of Real Option Analysis (ROA) method is the simple mathematic formula, as the formula in NPV method, is not found yet.
\end{abstract}

Keywords: Real Option Analysis (ROA)

ABSTRAK
Metode Net Present Value (NPV) telah populer semenjak pertengahan tahun 70-an dan
kini sebagian Akademisi dan Praktisi merasakan bahwa metode itu memiliki berbagai
keterbatasan, terutama bila digunakan untuk menganalisis alokasi modal dalam investasi dalam
skala besar, misalnya saja Merger, Proyek Penelitian dan Pengembangan, Eksplorasi Sumber
Daya Alam, dan sebagainya. Metode yang mulai populer adalah Real Option Analysis (ROA)
yang digunakan untuk menggantikan metoda NPV. Keunggulan relatif ROA dibandingkan NPV
adalah fleksibilitasnya dalam memberi informasi bagi para pengambil keputusan. Kelemahan
metode ROA itu adalah belum ditemukannya formula matematis yang cukup sederhana,
sebagaimana formula NPV.
Keywords: Real Option Analysis (ROA)

\footnotetext{
${ }^{1}$ Staf Pengajar STIE YPTK, Padang \& UBiNus, Jakarta
} 


\section{PENDAHULUAN}

Real Option dalam analisis ROA memiliki pengertian yang serupa dengan pengertian Opsi dalam manajemen keuangan, yakni pengakuan hak atas sesuatu namun tidak kewajiban untuk melakukannya pada harga tertentu selama periode tertentu. Perbedaan yang paling jelas adalah Real Option biasanya merupakan suatu tipe fleksibilitas manajerial dalam pengendalian suatu proyek. Hal itu dimungkinkan karena manajemen menguasai sepenuhnya suatu proyek dan mereka dapat meningkatkan nilai proyek berarti pada saat yang sama meningkatkan nilai fleksibilitas (baca:opsi) proyek tersebut.

Bila mengkaji suatu proyek dengan NPV maka langkah pertama yang dilakukan adalah melakukan prediksi arus kas masuk. Selanjutnya, diskontokan arus kas tersebut dengan biaya modal dan hasilnya mengurangi nilai investasi awal. Bila hasil pengurangan tersebut positif berarti proyek diterima (go project) dan bila sebaliknya maka proyek ditolak (reject project). Namun, dalam kenyataannya banyak manajer dan eksekutif menyadari bahwa NPV negatif bukan berarti "harga mati”, untuk kemudian tetap melanjutkan proyek dengan mengemukakan alasan bahwa hal tersebut dilakukan dengan pertimbangan 'strategis'. Sesungguhnya mereka memahami bahwa selalu ada opsi atau pilihan suatu proyek. Setidaknya terdapat 5 opsi suatu proyek sebagaimana Gambar 1 berikut ini.

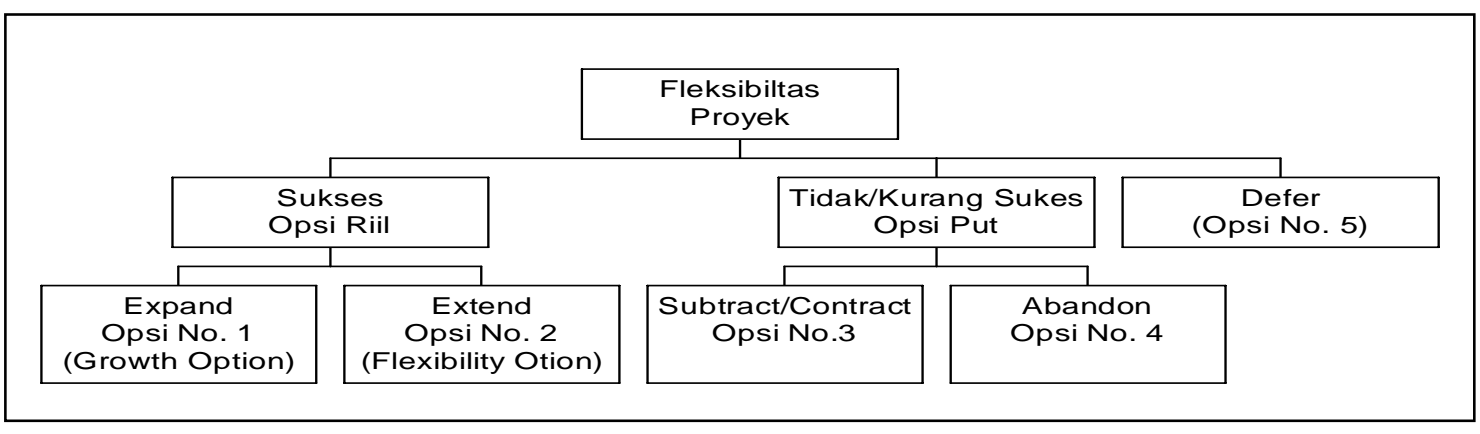

Gambar 1 Lima Opsi Proyek

Mari ambil contoh ilustrasi sebuah perusahaan minyak, sebut saja namanya Pusmanu yang mendapat konsensi eksplorasi dan eksploitasi atas sumber daya minyak dan gas. Pelaksanaan hak tersebut diawali dengan kegiatan eksplorasi mencari sumber daya minyak dan gas dan Proyek tersebut memiliki beberapa fleksibilitas sebagai berikut.

1. Bila Sukses, kegiatan tersebut dapat memiliki 2 pilihan, apakah (i) hendak diperpanjang (extend), misalnya dengan memperluas daerah eksplorasi; atau (ii) dikembangkan (expand) dengan kegiatan eksploitasi. Bila itu yang terjadi maka merupakan opsi yang sesungguhnya. Mengapa itu merupakan opsi? Karena Pusmanu memiliki hak tetapi bukan kewajiban untuk mengembangkan keberhasilan eksplorasi tersebut.

2. Bila kurang berhasil atau gagal, pilihannya dapat berupa (i) kegiatan eksplorasi dihentikan sama sekali (abandon); atau (ii) dikurangi (subtract). Bila eksplorasi gagal, Pusmanu 
memiliki hak kebebasan tetapi bukan kewajiban untuk menghentikan eksplorasi atau juga mengurangi kegiatan eksplorasi.

3. Opsi yang ke-5, yakni penundaan (defer) adalah bila situasi dan kondisi tidak menguntungkan maka kegiatan eksplorasi dapat ditunda atau dihentikan untuk sementara waktu hingga keadaannya memungkinkan.

\section{PEMBAHASAN}

\section{Mengapa Beralih dari NPV ke ROA?}

Secara sederhana, ROA mempertimbangkan hal yang tidak dapat dan tidak mampu dilakukan oleh NPV, yakni Nilai Fleksibilitas. Dalam dunia ketidakpastian, ROA menawarkan salah satu dari 5 opsi/pilihan di atas sebagai jawaban (respons) atas peristiwa di masa depan yang mungkin dapat menambah nilai proyek atau sebaliknya malah meniadakannya sama sekali. Sudah tentu opsi seperti itu harus dipertimbangkan dalam suatu analisis proyek semenjak tahap awal hingga sepanjang usia proyek itu sendiri.

ROA juga mampu mengeliminasi "false comparison" yang kerap terjadi bila menggunakan NPV. Sebagai ilustrasi, misalkan saja Pusmanu dalam contoh di atas memiliki opsi defer. Bila menggunakan NPV maka pilihan yang tersedia harus diperlakukan secara "mutually exclusive". Hal itu menuntut Pusmanu untuk mampu menyediakan cukup banyak alternatif proyek dan kemudian memilih alternatif yang memiliki nilai NPV tertinggi. ROA melihat masalah itu dengan kacamata berbeda, yakni dengan pohon keputusan (decision tree). Bila hal itu dilakukan maka dalam analisis tidak ada alternatif yang "mutually exclusive” yang ada hanyalah nilai NPV dan Decision role.

\section{Manfaat Kualitatif ROA yang Lain}

1. Untuk opsi riil, semakin tinggi tingkat volatilitas (ketidakpastian), semakin tinggi nilai opsi.

2. Setiap prakarsa atau inisiatif yang memiliki tingkat volatilitas tinggi dapat diterapkan dalam setiap tahapan proyek. Dengan demikian, manajemen dapat melakukan investasi dalam jumlah minimum pada tahapan awal proyek namun dalam waktu yang bersamaan manajemen dapat mengumpulkan data dan mempelajarinya. Hal itu akan memberi kemampuan bagi manajemen untuk mencari solusi terbaik dalam menghadapi ketidakpastian. Kelak investasi dalam jumlah yang lebih besar dapat dengan mudah dilakukan dalam lingkungan dengan tingkat volatilitas yang lebih rendah.

3. Suatu rangkaian prakarsa harus dianalisis berdasarkan sudut pandang portofolio. Dengan demikian, hasil pencapaian (performa) investasi (baca: portofolio) harus didasarkan pada hasil keseluruhan proyek dan bukan berdasarkan hasil setiap tahapan (prakarsa).

4. Opsi riil tetap memandang bahwa abandonment adalah sebuah alternatif yang harus tetap ada; dan bila hal itu terjadi, bukan berarti bahwa mereka yang bertanggungjawab atas suatu prakarsa tertentu telah gagal.

5. Harus diakui bahwa mencapai target nilai opsi riil adalah tidak mudah. Menentukan nilai opsi riil bukanlah hal yang utama namun pemahaman akan value driver dan nilai relatif antara metode ROA dan metoda NPV adalah lebih penting. 
6. Untuk alokasi modal dalam kegiatan penelitian dan pengembangan, merger dan akuisi, leasing, brand development, dan sebagainya maka kerap hanya ada satu macam opsi, yakni opsi riil. Namun, opsi tersebut dapat lagi dikaji lagi terlebih jauh menjadi sebagai berikut.

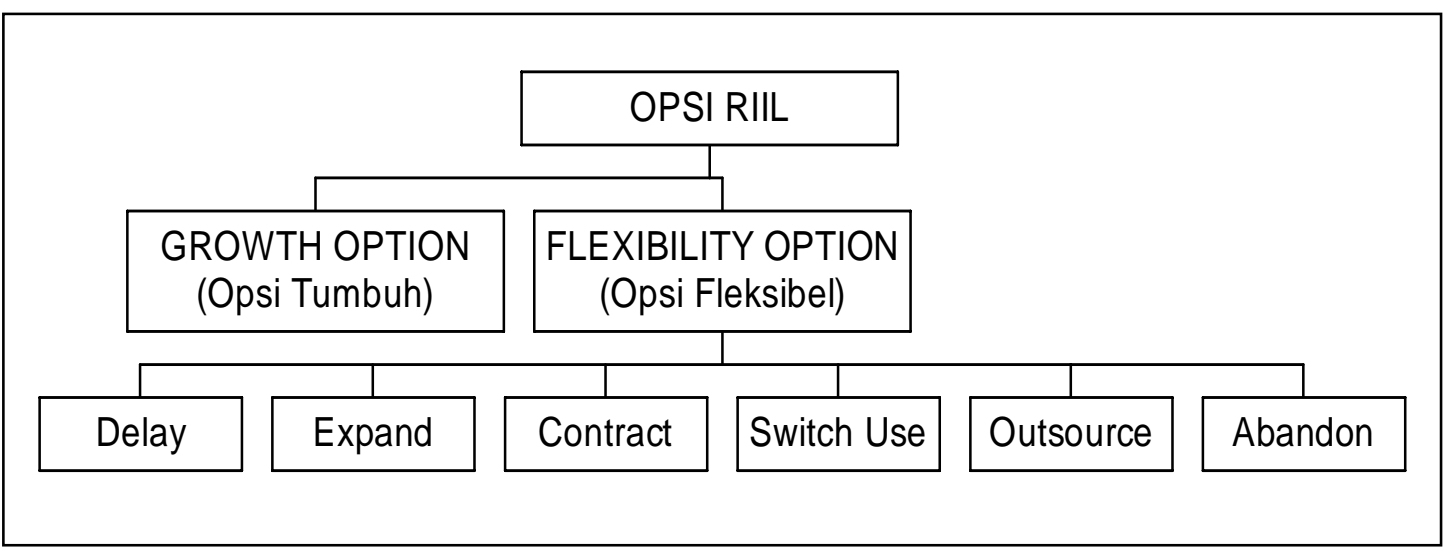

Gambar 2 Skema Opsi

Growth Option akan memberi kemampuan bagi perusahaan untuk meningkatkan nilai bisnisnya di masa datang. Siapapun tidak akan meragukan nikmatnya sukses kegiatan tersebut di atas. Flexibility Option disisi lain memberi kesempatan bagi perusahaan untuk merevisi rencananya dimasa mendatang. Hal itu sangat penting, terutama bila ada usia proyek cukup panjang dan musti melalui beberapa tahapan.

\section{Bilamana Analisis NPV Lebih Baik dari ROA?}

Bila analisis proyeksi arus kas menghasilkan hasil perhitungan nilai NPV sangat tinggi (extremely high), tidak membutuhkan fleksibilitas. Karena sudah pasti akan "GO PROJECT" dan opsi tidak akan pernah dipertimbangkan untuk digunakan karena rendahnya nilai opsi tersebut. Namun sebaliknya, bila situasinya sangat tidak pasti (penuh ketidakpastian), dan perhitungan nilai NPV sangat rendah (sangat negatif), serta disisi lain opsi yang tersedia tetap tidak fleksibel dalam mengahadapi ketidakpastian maka sudah cukup mendasarkan keputusan pada analisis NPV.

Dengan demikian, kesimpulannya adalah bilamana situasinya sangat pasti atau sangat tidak pasti maka model NPV jelas sudah memadai. Namun, bila situasinya adalah NPV relatif rendah terhadap nilai investasi maka ROA akan lebih powefull. Secara gamblang, dapat dikatakan bahwa gunakan NPV bila situasi investasi tidak memiliki fleksibilitas.

\section{Contoh Hipotetis}

Salah satu strategi ekspansi adalah dengan jalan merger dan akuisisi yang dikenal dengan sebutan "growth staircases". Misalkan, PT A merger dengan PT B dengan cara A mengakuisisi B dan bila merger ini sukses maka perusahaan baru hasil merger akan memiliki platform baru untuk berkembang lebih besar dengan lebih cepat. Namun, bila merger tahap pertama dirasakan kurang 
berhasil, tetap terbuka kemungkinan untuk mengakuisisi perusahaan lain melalui merger dengan perusahaan lainnya. Hal itu merupakan salah satu contoh aplikasinya.

Contoh berikutnya mengenai keputusan penutupan divisi atau salah satu lini usaha. Misalkan saja, sebuah perusahaan memiliki pabrik semi conductor. Situasi persaingan disini sangat kejam karena harga jual yang semakin berkurang. Bahkan dalam waktu tahun penurunan harga dapat mencapai 90\%. Penutupan pabrik secara seketika jelas membutuhkan biaya yang tidak sedikit dan bila langsung ditutup (exit strategy) kelak dikemudian hari untuk kembali memasuki pasar tidak mudah. Hal itu barangkali mirip dengan situasi yang dihadapi oleh raksasa elektronik Sony di Indonesia yang berencana untuk menutup pabriknya di kawasan EJIP Cibitung Bekasi yang kemudian mengebohkan masyarakat dengan keputusannya untuk merelokasi pabriknya keluar dari Indonesia pada sekitar April 2003.

Penulis tentu saja tidak mengetahui latar belakang keputusan Sony tersebut. Akan tetapi, dalam bahasan disini bila biaya penutupan pabrik di Indonesia dan pembukaannya kembali adalah nihil (baca: murah) maka keputusannya jelas tutup pabrik dengan segera. Mengapa demikian?. Karena bila operasi diteruskan maka Sony harus rela kehilangan dana (baca: rugi) untuk setiap unit keluaran (output) pabrik.

Namun, bila kondisinya adalah menunjukkan bahwa biaya bagi Sonny akan sangat mahal baik dalam penutupan pabrik dan juga pembukaannya kembali kelak maka metode ROA dapat memberi gambaran bagi Sony mengenai jangka waktu yang acceptable untuk terus merugi sebelum pabrik ditutup. Bagaimana hal tersebut dilakukan, berikut ilustrasinya.

1. Tahap pertama adalah menentukan nilai investasi yang tanpa fleksibilitas, tentu saja dengan metode NPV.

2. Tahap kedua mulai memasukkan unsur ketidakpastian. Manfaatkan Monte Carlo analysis. Hasil tahapan ini adalah sebuah pohon keputusan (decision tree) yang hanya terdiri dari dua macam kemungkinan pergerakan, yakni turun atau naik; dan nilainya adalah nilai saat ini tanpa fleksibilitas. Pohon keputusan itu istilah lainnya adalah binomial tree atau lattice.

3. Tahap ketiga pada setiap titik (node) dari lattice tersebut, tuliskan keputusan atau opsi yang dapat diambil, apakah ekspansi, atau bahkan abandonment.

4. Tahap terakhir kembangkan pohon keputusan tersebut sesuai dengan umur opsi. Lakukan analisis dimulai dari titik terjauh dari pohon keputusan tersebut. Jangan lupa bahwa titik terjauh harus sesuai dengan umur atau usia opsi tersebut.

5. Langkah terakhir adalah tuliskan keputusan yang paling optimal pada setiap node. Lakukanlah dari ujung terjauh kemudian mundur hingga node yang mengambarkan situasi saat ini. Ilustrasi pohon keputusan tersebut sebagai berikut. 


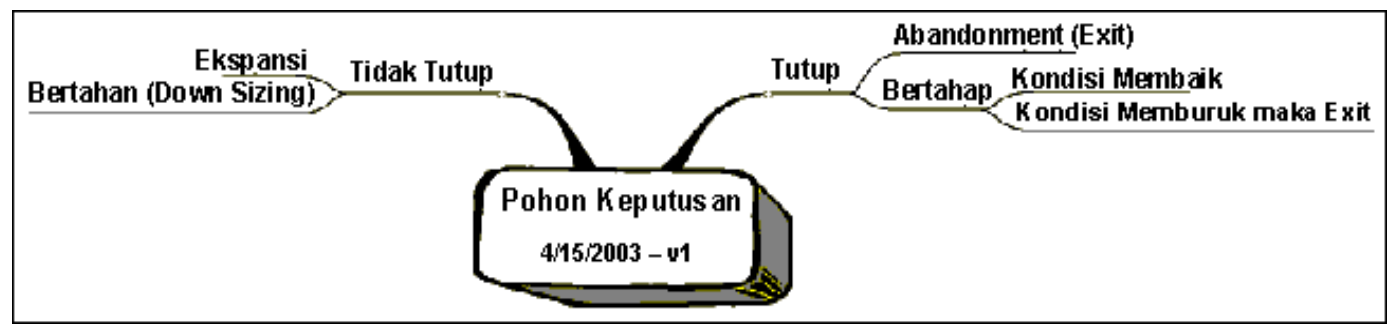

Gambar 3 Ilustrasi Keputusan

\section{ROA dan Manajemen Risiko}

Menurut penulis, ROA juga dapat dikaitkan dengan manajemen risiko (risk management), contohnya dalam peanggaran modal (capital budgetting) dalam jangka waktu tertentu dan tingkat volatilitas industri sangat tinggi, misalnya saja industri berbasis Hak Penggunaan Hutan (HPH) seperti usaha kayu olahan (plywood) yang bahan bakunya adalah kayu gelondongan atau industri furnitur yang bahan bakunya kayu jati.

Volatilitas dalam industri seperti itu adalah pada kepastian bahan baku (raw material) dan kerap sisi suplai sangat ditentukan kepastian oleh hukum dan peraturan yang berlaku. Pada saat hukum dan peraturan sangat lemah, baik dari sisi teknis maupun penegakkannya maka dapat diharapkan adanya suplai yang melimpah dengan harga murah. Namun pada suatu saat, bila kondisi alam sudah sangat rusak yang kemudian diikuti dengan penegakkan hukum yang keras dan ketat maka pasokan bahan baku akan seret dan harganya melambung. Tentu saja kelangkaan dan mahalnya bahan baku dapat mengancam kelangsungan hidup industri.

Untuk mengatisipasi hal itu maka industri yang berbasis HPH memiliki 2 opsi, yakni membeli HPH (baca: memiliki) atau membeli kebutuhan bahan bakunya sebagaimana diperlukan pada saatnya. Memiliki HPH pun belum tentu menjamin kepastian pasokan bahan baku karena masih disertai kemungkinan penjarahan, dan perubahan peraturan, dan perundangan yang berlaku.

\section{Ilustrasi Hipotetis}

Misalkan saja manajemen Pusmanu Furniture sedang mempertimbangkan strategi pengadaan bahan baku kayu jati untuk jangka waktu 5 tahun mendatang. Ada 2 alternatif yang dapat ditempuh, yakni membeli bahan baku pada saat diperlukan atau membeli kontrak HPH Kaju jati pada Perhutani. Berdasarkan situasi dan kondisi saat ini maka perusahaan memprediksikan arus kas bersih (NPV) sebagai berikut.

Tabel 1 NPV Kedua Alternatif

\begin{tabular}{llll}
\hline & PV Kayu Jati & PV HPH & NPV \\
\hline Membeli HPH & Rp. 5 Milyar & Rp. 6 Milyar & Rp. 1 Milyar \\
\hline Pembelian bahan baku pada saat dibutuhkan & Rp. 5 Milyar & Rp. 6 Milyar & Rp. 1 Milyar \\
\hline
\end{tabular}


Untuk menyederhanakan masalah perhitungan, diasumsikan kenaikan harga pada alternatif membeli bahan baku pada saat dibutuhkan saling menghilangkan (offset) tingkat diskonto. Dengan demikian, nilai pembelian HPH saat ini (alternatif 1) dengan nilai alternatif kedua adalah sama 5 miliar rupiah. Arus kas dalam 5 tahun mendatang adalah 6 miliar rupiah untuk kedua alternatif sehingga kedua alternatif memiliki nilai arus kas bersih (NPV) 1 miliar rupiah.

Manajemen Pusmanu mulai memasukkan unsur ketidakpastian dan dalam 5 tahun mendatang ada tiga kemungkinan perubahan situasi dan kondisi peraturan berkenaan dengan $\mathrm{HPH}$ sebagai berikut.

1. Peraturan Diperketat. Peluang 30\%

2. Peraturan Tetap sama (tidak ada perubahan berarti). Peluang $60 \%$

3. Peraturan Diturunkan, peluang $10 \%$ berikut.

Bila ketiga kemungkinan tersebut dikaitkan dengan Tabel 1 maka hasilnya sebagai

Tabel 2 Ekspetasi PV dari Ketiga Skenario Perubahan Peraturan HPH

\begin{tabular}{|c|c|c|c|c|}
\hline Tingkat peraturan & Probilitas & $\begin{array}{l}\text { PV Kebutuhan } \\
\text { Bahan Baku }\end{array}$ & PV Beli & PV HPH \\
\hline Diperketat & $30 \%$ & Rp. $6.5 \mathrm{M}$ & Rp. $7.0 \mathrm{M}$ & Rp. $5.0 \mathrm{M}$ \\
\hline Tetap Sama & $60 \%$ & Rp. $5.0 \mathrm{M}$ & Rp. $5.0 \mathrm{M}$ & Rp. $5.0 \mathrm{M}$ \\
\hline Diturunkan & $10 \%$ & Rp. $4.5 \mathrm{M}$ & Rp. $3.0 \mathrm{M}$ & Rp. $5.0 \mathrm{M}$ \\
\hline
\end{tabular}

\begin{tabular}{|c|c|c|c|c|c|c|}
\hline & $\begin{array}{l}\text { Tirgkkat } \\
\text { Peratuman }\end{array}$ & $\begin{array}{l}\text { Frobabilitas } \\
\text { (A) }\end{array}$ & $\begin{array}{l}\text { FV Keb Bhr Baka } \\
\text { (B) }\end{array}$ & $\begin{array}{l}\text { PV Biaya } \\
\text { (C) }\end{array}$ & $\begin{array}{l}\mathrm{NPV} \\
(\mathrm{D})=(\mathrm{B})-(\mathrm{C})\end{array}$ & $\begin{array}{l}\mathrm{EV} \\
(\mathrm{A}) \times(\mathrm{D})\end{array}$ \\
\hline \multirow{3}{*}{4} & Ketat & $30 \%$ & Rp. $6.5 \mathrm{M}$ & Rp. $50 \mathrm{M}$ & Rp. $1.5 \mathrm{M}$ & $\mathrm{Rp} 0.4 \mathrm{M}$ \\
\hline & TetapSarna & $60 \%$ & Rp. $6.0 \mathrm{M}$ & Rp. $50 \mathrm{M}$ & Kp. $1.0 \mathrm{MI}$ & Rp. $0.60 \mathrm{M}$ \\
\hline & Mekmah & $10 \%$ & Rp. $4.5 \mathrm{M}$ & $\mathrm{Rp} .5 .0 \mathrm{M}$ & (Rp. O.JM & (Rp. $0.05 \mathrm{M}$ \\
\hline \multirow{2}{*}{ FUTUS } & Tirgkat & Frobabilitas & PV Keb Blw Bakı & FV Biaya & NFV & EV \\
\hline & Peratman & (A) & & & (D) $=(\mathrm{B}), \mathrm{C})$ & $(\mathrm{A}) \times(\mathrm{D})$ \\
\hline \multirow{3}{*}{$\begin{array}{l}\text { BeliF a saat } \\
\text { metr buthikan }\end{array}$} & Ketat & $30 \%$ & $\mathrm{Rp} 6.5 \mathrm{M}$ & Fp. $7.0 \mathrm{M}$ & (R.p. $0.5 \mathrm{M}$ & (Rp $0.15 \mathrm{M})$ \\
\hline & $\begin{array}{l}\text { TetapSana } \\
\end{array}$ & $60 \%$ & Rp. $6.0 \mathrm{M}$ & Rp. $5.0 \mathrm{M}$ & Rp. $1.0 \mathrm{M}$ & $\mathrm{Rp} .0 .60 \mathrm{M}$ \\
\hline & Melemah & $10 \%$ & Rp. $4.5 \mathrm{M}$ & Rp. $30 \mathrm{M}$ & Rp. $1.5 \mathrm{M}$ & Kp. $0.15 \mathrm{M}$ \\
\hline
\end{tabular}

Dari ilustrasi tersebut tampak bahwa nilai alternatif ke-1, yakni membeli HPH tampak lebih menjanjikan dibandingkan alternatif kedua. Total EV alternatif pertama, yakni 1 miliar rupiah dibandingkan dengan 0,6 miliar rupiah dialternatif kedua. Namun, masalahnya tidak sesederhana itu. Bila Pusmanu memutuskan membeli HPH dan bila dalam 5 tahun mendatang peraturan justru diperlunak, misalkan saja dikarenakan "euforia” otonomi daerah maka keputusan ini akan mungkin berakibat kerugian sebesar 0,5 miliar rupiah.

Bila Pusmanu memilih alternatif ke-2, yakni menangguhkan pembelian hingga saat datangnya kebutuhan maka bila peraturan diperketat umpamanya dikarenakan kesadaran Pemda untuk melestarikan hutan dapat berakibat fatal dengan kenaikan harga bahan baku dan perusahaan akan mengalami kerugian sekitar 0,5 miliar rupiah. 


\section{Pros dan Cons Metode ROA dengan Pohon Keputusannya}

Tentu saja metode itu tidak lepas dari pro dan kontra. Mereka yang pro mengungkapkan kelebihan metode ini adalah pohon keputusan memungkinkan bagi para pengambil keputusan untuk melakukan analisis secara eksplisit mengenai probabilitas kejadian di masa mendatang dan keputusan apa yang sekiranya relevan. Karena hubungan antara keputusan saat ini dan kejadian di masa depan mampu ditampilkan secara 'visual', para pengambil keputusan diharapkan akan lebih rasional. Penilaian manfaat ROA dengan pohon keputusannya tidak dapat didasarkan atas kelengkapan alias komprehensifitasnya namun harus didasarkan atas kemampuannya menyajikan hubungan antara keputusan saat ini dengan masa mendatang.

Penyajian contoh ilustrasi di atas tentu saja telah disederhanakan. Dalam realitanya, para pengambil keputusan kerap menaruh perhatian pada berbagai faktor seperti inlasi, perubahan peraturan, kondisi politik dan keamanan, dan sebagainya. Walau hal tersebut dapat secara bersamaan dimasukkan ke dalam analisis pohon keputusan, pohon keputusan dapat menjadi sangat kompleks. Tidaklah mengherankan bila dalam analisis ROA, jumlah cabang pohon keputusan dibatasi sebab bila tidak dilakukan maka pohon keputusan dapat berkembang menjadi sesuatu yang sangat rumit untuk dianalisis bahkan oleh seorang yang sangat berpengalaman.

\section{PENUTUP}

\section{Simpulan}

Walau telah dibuktikan bahwa ROA memiliki kelebihan atas metode PV namun belum ditemukannya rumus matematis sederhana sebagaimana NPV menjadikan ROA belum populer. Salah satu cara terbaik menampilkan analisis ROA adalah menggunakan pohon keputusan (decision tree). Namun, menggunakan pohon keputusan pun tidak atau belum mampu menampilkan seluruh kelebihan atau kekuatan analisis ROA. Hal itu disebabkan oleh kelemahan pohon keputusan itu sendiri. Namun, karena dalam prakteknya analisis ROA membatasi pilihan keputusan, tetap sementara ini pohon keputusan merupakan alat analisis terbaik untuk melakukan ROA.

\section{DAFTAR PUSTAKA}

Anonymous. 2002. "Real Options: Move Over NPV.” Financial Executive International (FEI) Magazine.

Bailes, Jack C. and James F. Nielsen. 2001. "Using Decision Tree to Manage Capital Budgetting Risk.” Management Accounting Quarterly. Winter. 